СОЦІАЛЬНИЙ ЗАХИСТ ПРАВ МОЛОДІ:

\title{
SOCIAL PROTECTION OF YOUTH RIGHTS: RESPONSE TO THE CHALLENGES OF OUR TIME
}

\begin{abstract}
У статті висвітлено сучасні виклики суспільства щодо змісту профресійної підготовки фрахівця із соціального захисту прав молоді. Окреслено специфріку професійної діяльності фрахівців із захисту прав молоді. Розкрито сутність понять «соціальний захист», «соціальне забезпечення молоді». Представлено авторське визначення поняття «соціальний захист», яке розглядається як об'єкт державного управління і є системою економічних, правових та організаційних заходів держави щодо забезпечення сочіальних прав і гарантій молодої людини. Висвітлено основні організаційно-правові та соціально-економічні заходи реалізації державної соціальної політики в Україні щодо соціального захисту прав молодих людей. Наведено перелік нормативно-правових документів щодо реалізації соціального захисту прав молоді. Розкрито змістові характеристики чинних нормативно-правових актів із соціального захисту прав дітей і молоді, таких як Декларація «Про загальні засади державної молодіжної політики в Україні» (1992р.), Закон України «Про сприяння соціальному становленню та розвитку молоді в Україні» (1993 р.), Декларація Міжнародної організації праці «Про соціальну справедливість» (1998р.), Конститучія України (1996р.), «Концепція Державної цільової сочіальної програми «Молодь України» на 2016-2020 роки» щодо питань соціального захисту прав молоді. Визначено пріоритетні загальнодержавні напрями діяльності щодо соціального захисту прав молоді. Висвітлено мету практичноі діяльності фрахівців із соціального захисту прав молоді, яка полягає у фраховому використанні у професійній діяльності набутих знань із соціально-правового захисту молоді. Окреслено потенційні соціальні ризики щодо забезпечення соціальних прав і гарантій молодої людини. Виокремлено форми соціального захисту прав молоді за стандартами Ради Європи.
\end{abstract}

Ключові слова: соціальний захист, соціальне забезпечення, соціальна політика, молодь.

The article highlights the contemporary challenges of society regarding the content of professional training of a specialist in social protection of youth rights. The specifics of the professional activity of youth protection professionals are outlined. The essence of the concepts of "social protection", "social security of youth" is revealed. The author defines the concept of "social protection", which is considered as an object of public administration is a system of economic, legal and organizational measures of the state to ensure social rights and guarantees of a young person. The main organizational, legal and socio-economic measures of realization of the state social policy in Ukraine concerning social protection of the rights of young people are covered. The list of normative legal documents on realization of social protection of youth rights is given. The substantive characteristics of the current legal acts on social protection of the rights of children and youth are disclosed, such as: Declaration "On the General Principles of State Youth Policy in Ukraine" (1992), Law of Ukraine "On Promoting the Social Formation and Development of Youth in Ukraine" (1993), Declaration of the International Labor Organization "On Social Justice" (1998), Constitution of Ukraine (1996), "Concept of the State Target Social Program "Youth of Ukraine for 2016-2020" on social issues protection of youth rights. Priority national directions of activity on social protection of youth rights were identified. The purpose of the practical activity of specialists in social protection of youth rights is highlighted, which consists in the professional use in the professional activity of the acquired knowledge in social and legal protection of youth. The potential social risks to the social rights and guarantees of the young person are outlined. Forms of social protection of youth rights according to Council of Europe standards have been identified.

Key words: social protection, social security, social policy, youth.
Постановка проблеми у загальному вигляді. Сучасна соціальна ситуація, що склалася в Україні, породжує нову соціально-культурну реальність, одним із пріоритетів якої $\epsilon$ молодіжна політика країни, що розглянуто у низці державних документів, таких як «Стратегія сталого розвитку України до 2030 р. (проект-2017)» [16], Декларація «Про загальні засади державної молодіжної політики в Україні» (1992р.) [2], Закон України «Про сприяння соціальному становленню та розвитку молоді в Україні» (1993р.) [15], Декларація Міжнародної організації праці «Про соціальну справедливість» (1998р.) [2], Конституція України (1996р.) [4], Концепція Державної цільової соціальної програми «Молодь України» на 2016-2020 роки» щодо питань соціального захисту прав молоді, в яких визначено пріоритетні загальнодержавні напрями діяльності щодо соціального захисту прав молоді, План дій Ради Європи для України на 2018-2021 рр. [11].

Аналіз останніх досліджень і публікацій. Формуванню профресійної компетентності соціального працівника присвячені дослідження вітчизняних і зарубіжних учених, зокрема А. Белінської, О. Безпалько, В. Бочарової, І. Звєрєвої, А. Капської, О. Карпенко, А. Ляшенка, Л. Мардахаєва, І. Миговича, С. Омельченко, Г. Попович, В. Сидорова, С. Харченка, Є. Холостової, Н. Чернухи та ін. Проблеми соціального захисту молоді залишаються в центрі постійного наукового інтересу багатьох українських і зарубіжних науковців, серед яких 
С. Алупко, В. Гайдуцький, І. Гнибіденко, Е. Лібанова, О. Палій, А. Сіленко, А. Скуратівський та ін.

Виділення невирішених раніше частин загальної проблеми. Отже, характер молодіжної політики, зокрема політики зайнятості в Україні та соціального захисту прав молоді, вимагає приділення особливої уваги в межах загальної системи соціального захисту категорій економічно активного населення, які найшвидше виштовхуються з ринку праці, де нерідко найбільш незахищеною $є$ молодь. Відтак покращення становища молоді, її соціальний захист, що забезпечує реалізацію творчого і трудового потенціалу, а також належний добробут молодих людей $€$ одним із головних напрямів соціальної політики в Україні $[1 ; 12 ; 13 ; 19 ; 21]$.

Мета статті полягає у висвітленні сучасних запитів суспільства щодо соціального захисту прав молоді.

Виклад основного матеріалу. У контексті нашого дослідження зазначимо, що соціальний захист як об'єкт державного управління $€$ системою економічних, правових та організаційних заходів держави щодо забезпечення соціальних прав і гарантій молодої людини.

Соціальний захист - це практична діяльність щодо створення сприятливого навколишнього середовища, охорони материнства та дитинства, здійснення допомоги сім'ї, охорони здоров'я громадян, професійної підготовки громадян, забезпечення зайнятості населення, охорони праці, регулювання заробітної плати та доходів населення, забезпечення громадян житлом, регулювання права власності громадян, матеріального обслуговування та забезпечення непрацездатних та інших осіб, котрі потребують соціальної підтримки [9].

Соціальний захист полягає у реалізації основних напрямів соціальної політики завдяки комплексу організаційно-правових і соціально-економічних заходів, метою яких є:

- створення для працездатних громадян належних умов для забезпечення їхніх соціальноекономічних і духовних потреб;

- гарантоване забезпечення рівня доходу не нижчого за прожитковий мінімум громадянам, котрі потребують соціальної допомоги [9].

Більш вузько соціальний захист можна визначити як обов'язок суспільства, який реалізує держава щодо утримання конкретної категорії громадян в особливих випадках та особливими засобами за рахунок суспільства завдяки мережі державних органів, органам місцевого самоврядування, громадським організаціям.

Соціальне забезпечення молоді, що є важливою складовою частиною соціального захисту, це державна система захисту від соціальних ризиків, конорліктів сімейних, освітянських тощо, які виникають внаслідок незахищеності молоді. Від- так увага державних інститутів повинна бути зосереджена на середовищі проживання людини, його екологічних елементах, вирішенні соціальних, економічних і моральних проблем середовища [10].

Доцільно взяти до уваги те, що 15 грудня 1992 р. Верховна Рада України прийняла Декларацію «Про загальні засади державної молодіжної політики в Україні», а 05 лютого 1993 р. - Закон України «Про сприяння соціальному становленню та розвитку молоді в Україні» [7], де визначаються загальні засади створення організаційних, соціально-економічних, політико-правових умов соціального становлення та розвитку молоді, основні напрями реалізації державної молодіжної політики в Україні.

До основних напрямів державної соціальної політики в Україні щодо соціального захисту прав молодих людей відносять [5]: підвищення доходів до рівня життя громадян, забезпечення зайнятості молоді та задовільний стан ринку праці, належну організацію й оплату праці, загальнообов'язкове державне соціальне страхування, пов'язане з трудовою діяльністю, окремі грошові виплати; допомогу молодим сім'ям із дітьми, адресну соціальну допомогу малозабезпеченим сім'ям, надання житлових субсидій молодим людям, молодим сім'ям і одиноким матерям, компенсації та пільги тим, хто постраждав від техногенних, економічних, природних катастроф, військових дій і мають хворих дітей тощо.

Необхідно взяти до уваги, що в Україні нині немає дієвого механізму захисту від впливу потенційних соціальних ризиків (зокрема для сімей із дітьми, непрацездатних та осіб, які за ними наглядають, людей з інвалідністю, вимушено безробітних, переселенців, учасників бойових дій тощо).

Згідно 3 «Декларацією Міжнародної організації праці про соціальну справедливість» (1998р.) [2] у цілях справедливої глобалізації стрижневим елементом економічної та соціальної політики будь-якої країни є повна і продуктивна зайнятість.

3 одного боку, це означає сприяння якомога ширшому виведенню працездатного (в т. ч. частково працездатного) населення на відкритий ринок праці. 3 іншого - саме доходи від повної та продуктивної зайнятості фрормують страхову й фріскальну базу систем соціального захисту задля зменшення впливу соціальних ризиків і повернення особи на ринок праці. У цьому контексті держава бере на себе впровадження програм розвитку ринку праці, підвищення рівня життя населення, забезпечення мінімальної заробітної плати, здійснення заходів соціального забезпечення для тих, хто його потребує.

Враховуючи означене, констатуємо, що соціальний захист стає не стільки механізмом кризового втручання, скільки стратегією профілактики негативного впливу можливих соціальних ризиків і не лише усуває наслідки соціальної нерівності, а й 
передбачає збалансований перерозподіл суспільних благ, стаючи способом зменшення нерівності та подолання (недопущення) маргіналізації окремих осіб, сімей і соціальних груп у спосіб:

- дотримання принципів самозабезпечення економічно активної частини населення, тобто створення умов для того, щоб працююча особа мала змогу заробляти стільки, скільки дозволяють іï здібності та ініціатива; забезпечувати себе та свою сім'ю; сплачувати податки, у т. ч. й на соціальний захист інших;

- забезпечення гарантованого рівня та якості життя тих членів суспільства, які не в змозі досягти його самостійно, завдяки заходам соціальної підтримки найуразливіших верств населення.

У ч. 1 ст. 46 Конституції України зазначено: «Громадяни мають право на соціальний захист, що включає право на забезпечення їх у разі повної, часткової або тимчасової втрати працездатності, втрати годувальника, безробіття з незалежних від них обставин, а також у старості та в інших випадках, передбачених законом» [4], тобто соціальний захист не обмежується забезпеченням у разі настання ризику.

Сьогодні державна політика щодо соціального захисту прав молоді пріоритетами виділяє: персональну відповідальність найманих працівників, їх роботодавців, інших категорій працюючих і працездатних осіб за фрінансове забезпечення прийнятного рівня соціального захисту; солідарну підтримку працюючим населенням і роботодавцями найменш захищених категорій населення та їхніх сімей; оптимальну підтримку (принцип субсидіарності), що визначає міру (межі) солідарної підтримки, фріксує ії розмір і форми надання [3].

Так, за стандартами Ради Європи, соціальне забезпечення включає, крім матеріального забезпечення (завдяки соціальному страхуванню), також інші фрорми соціального захисту: державну соціальну допомогу, спеціальний і особливий (додатковий) соціальний захист тощо.

Міжнародне бюро праці визначає важливість горизонтального (якомога повнішого охоплення населення соціальними гарантіями) та вертикального (поступового забезпечення більш високих гарантій отримання доходу й охорони здоров'я з урахуванням економічного та соціального розвитку за виникнення соціальних ризиків - безробіття, хвороби, інвалідності, народження дитини, втрати годувальника, похилого віку тощо) компонентів соціального забезпечення.

У контексті нашої статті зазначимо, що системоутворюючу роль у побудові роботи із захисту прав молоді відіграє державна молодіжна політика, зокрема Концепція Державної цільової соціальної програми «Молодь України» на 2016-2020 роки [8], що має на меті створення сприятливих умов для розвитку та самореалізації української молоді, фрормування патріота і громадянина, визначає загальнодержавні пріоритети та напрями молодіжної політики, ґрунтуючись на найактуальніших проблемах молоді, таких як:

- високий рівень захворюваності та смертності, слабка мотивація до дотримання здорового і безпечного способу життя;

- низький рівень зайнятості на ринку праці за обраною професією; повільні темпи розвитку молодіжного підприємництва;

- недостатне використання інноваційного потенціалу молоді;

- низька якість загальної освіти, недостатнє застосування потенціалу несормальної освіти 3 метою підвищення конкурентоспроможності молоді на ринку праці;

- низький рівень забезпечення молодих сімей власним і соціальним житлом; несистемний характер фрормування у молодих людей громадянської позиції та патріотизму;

- відсутність сталої тенденції зниження рівня злочинності у молодіжному середовищі, насильства та системної роботи у сфері ії̈ профрілактики;

- низький рівень організації та культури молодіжного дозвілля;

- слабка інтегрованість української молоді у європейське та світове молодіжне співтовариство [8].

Впровадження ефрективної та цілеспрямованої молодіжної політики із захисту прав молоді можливе тільки за умови об'єднання спільних зусиль i координації діяльності державних органів, органів місцевого самоврядування й молодіжного представництва. Саме тому при Мінрегіоні діє Рада донорів із питань впровадження ресрорми місцевого самоврядування та територіальної організації влади в Україні, до складу якої входять представники центральних органів виконавчої влади, асоціацій органів місцевого самоврядування та близько 20 міжнародних донорських проектів і організацій, експерти. Сьогодні триває процес розроблення та впровадження типових моделей організації єдиного соціально-гуманітарного простору в різних видах адміністративно-територіальних одиниць базового рівня, в яких розвиток молодіжної політики повинен займати пріоритетні позиції.

Відтак на національному рівні центральним органом виконавчої влади, що забезпечує фрормування молодіжної політики та її реалізацію, $€$ Міністерство молоді та спорту України, яке має виконувати такі фрункції: нормативно-правове забезпечення; формування стратегії розвитку та пріоритетних напрямів молодіжної політики, зокрема виховання свідомої та відповідальної молоді (фрормування національної ідеї); забезпечення підвищення кваліфікації молодіжних працівників; методичну підтримку з урахуванням міжнародного досвіду та найкращих практик; 
фрінансування або сприяння у залученні фрінансових коштів на реалізацію програм, проектів, конкурсів тощо [6].

Міністерство молоді та спорту України взаємодіє з молодіжними громадськими консультативнодорадчими органами, залучає інші заінтересовані сторони через Громадську раду при Міністерстві.

Регіональний рівень відповідає за реалізацію молодіжної політики у межах підходів, запропонованих на національному рівні, зокрема в межах Державної цільової соціальної програми «Молодь України». На своєму рівні також можуть бути розроблені та прийняті регіональні програми, орієнтовані на потреби молоді, з урахуванням місцевих особливостей. Головними інструментами реалізації молодіжної політики на регіональному рівні в умовах децентралізації може виступити громадська рада як консультативно-дорадчий орган при обласній державній адміністрації, де може працювати комітет із питань молоді та яку представники місцевих громад використовуватимуть як платорорму для обміну думок, напрацювань і досвіду, у т. ч. для вироблення стратегії розвитку та пріоритетів молодіжної політики на регіональному рівні, коли необхідно продумати не тільки діяльність, але й фрінансування на її здійснення (державний / регіональний / місцевий бюджет; залучення донорських коштів, залучення коштів бізнес-структур, що працюють на місцевому рівні). Молодіжна політика в Україні донедавна регулювалася й адмініструвалася державними органами; напрями, завдання молодіжної політики, форми роботи, обсяги та напрями фрінансування фрормувалися адміністративним шляхом.

Висновки. Наприкінці зазначимо, що для ефрективної реалізації молодіжної політики, а саме захисту прав молоді слід дотримуватися таких дій: здійснювати організаційне та фрінансове забезпечення необхідної інфрраструктури молодіжної політики; забезпечувати діяльність молодіжних центрів і молодіжних працівників; сприяти формуванню та розвитку інститутів громадянського суспільства; налагоджувати міжгалузеву та міжсекторальну взаємодії у молодіжній роботі; здійснювати оцінки ефективності молодіжної роботи на рівні громади та звітувати перед громадою про стан роботи з молоддю; забезпечувати належні умови молодіжної участі та молодіжного громадського контролю. Саме тому сьогодні важливо не тільки забезпечувати координацію молодіжної роботи, але й активно залучати молодь до життя місцевих громад.

\section{БІБЛІОГРАФІЧНИЙ СПИСОК:}

1. Вольнова Л.М. Особливості середовища великого міста як чинника соціалізації / десоціалізації сучасної молоді. Соціальна робота в Україні: теорія і практика. 2011. № 3-4. С. 23-31.
2. Декларація МОП про соціальну справедливість в цілях справедливої глобалізації. Труд за рубежом. 2008. № 4. С. 142-156.

3. Дутчак А.В. Соціальне забезпечення громадян: сучасний стан та перспективи розвитку. Молодий вчений. 2017. № 5 (45). URL: http://molodyvcheny.in.ua/files/journal/2017/5/126.pdf (дата звернення: 01.08.2019).

4. Конституція України. Відомості Верховної Ради України. 1996. URI: http://www.president.gov.ua/ content/constitution.html (дата звернення: 01.08.2019).

5. Кулик О.М. Соціальний захист молоді - шлях до демократизації управлінської діяльності та попередження конфрліктів в українському суспільстві. Актуальні проблеми навчання та виховання людей з особливими потребами : збірник наукових праць. Київ : Ун-т «Україна», 2007. № 3 (5). С. 484-491.

6. Про Міністерство молоді та спорту України : Постанова Кабінету Міністрів України № 220 від 02 липня 2014 р. URL: https://zakon.rada.gov.ua/ laws/show/220-2014-\%D0\%BF (дата звернення: 01.08.2019).

7. Про загальні засади державної молодіжної політики в Україні : Декларація від 15 грудня 1992 р. № 2859-XII (зі змінами). URL: http://zakon0.rada.gov.ua/ laws/show/2859-12 (дата звернення: 01.08.2019).

8. Про схвалення Концепції Державної цільової соціальної програми «Молодь України» на 2016-2020 роки»: Розпорядження Кабінету Міністрів України № 1018-р від 30 вересня 2015 р. URL: http://www.president.gov.ua/content/constitution.html (дата звернення: 01.08.2019).

9. Соціальний захист населення України / за заг. ред. В.М. Вакуленка, М.К. Орлатого. Київ : НАДУ; Фенікс, 2010. 212 с.

10. Халецька А.А. Соціальний захист населення в Україні: теорія та практика державного управління : монографрія. Донецьк : Юго-Восток, 2010. 430 с.

11. План дій Ради Європи для України на 2018-2021 рр. / Комітет міністрів Ради Європи, ухвалено 21 лютого 2018 р. (CM/Del/Dec(2018)1308/ 2.1bisc). 2018. 40 c. URI: https://rm.coe.int/ coe-action-plan-for-ukraine-2018-2021-ukr/1680925bec (дата звернення: 01.08.2019).

12. Петько Л.В. Виклики XXI століття для освітнього простору України. Наукові праці. Серія : Педагогіка / Чорном. держ. ун-т імені Петра Могили; ред. кол. : О.П. Мещанінов та ін. Миколаїв : Вид-во ЧНУ імені Петра Могили, 2017. Т. 303. Вип. 291. С. 10-14.

13. Петько Л.В. Реалізація концепції підготовки магістрів в Україні для роботи в інклюзивному освітньому просторі. Актуальні проблеми навчання та виховання людей в інтегрованому освітньому середовищі : Праці XI Міжнар. наук.-практ. конф., листопад 2011 р. Ч. І. Київ : ВМУРЛ «Україна». 2011. С. $92-94$

14. Петько Л.В. Філософсько-лінгвістичні ідеї розуміння міжлюдської комунікації у соціальному середовищі. Наукові записки. Серія «Філологічна» / укл. І.В. Ковальчук, Л.М. Коцюк, С.М. Новоселецька. Острог : Вид-во Національного ун-ту «Острозька академія», 2015. Вип. 53. С. 309-312.

15. Просприяннясоціальномустановленнютарозвитку молоді в Україні : Закон України (1993 р.); редак- 
ція від 09 серпня 2019 URL: https://zakon.rada.gov.ua/ laws/show/2998-12 (дата звернення: 01.08.2019).

16. Стратегія сталого розвитку України до 2030 (проект-2018). Київ, 2017.112 c. URL: https://www.undp. org/content/dam/ukraine/docs/SDGreports/UNDP Strategy_v06-optimized.pdf (дата звернення: 01.08.2019).

17. Чернуха Н.М. Інтеграційна єдність навчання і виховання у сучасному освітньому просторі вищого навчального закладу. Вісник Черкаськогоун-ту. Серія «Педагогічні науки». 2014. № 24 (317). С. 125-130.

18. Чернуха Н.М. Інтеграційні процеси у вищій школі : навчальний посібник. Київ : Київський ун-т імені Бориса Грінченка, 2015. 92 с.

19. Чернуха Н.М., Асланов Г. Соціальні комунікації в інтеркультурному просторі: відповідь на виклики сьогодення. Innovative processes in education: collective monograph.AMEETSp.zo.o., Lodz, Poland, 2017.

20. Karpenko O.G. The formation of professionalism in future social workers in the conditions of higher school. Geopolitical processes in the world today: collection of scientific articles. "EastWest" Association for Advanced Studies and Higher Education. Vienna (Austria). 2016. P. 301-304.

21. Nagornyuk L., Pet'ko L. Leisure of Youth in Modern Society. Věda a vznik - 2013/2014 : Materiály X mezinárodní vědecko-praktická konference Díl 13. Ekonomické vědy. Administrativa. ; Šéfredaktor: Zdeněk Černák. Praha : Publishing House "Education and Science" s.r.o, 2014. S. 92-94. 